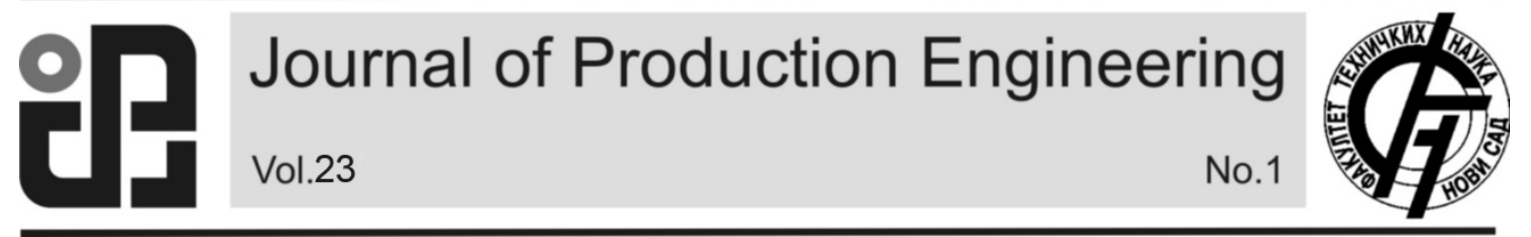

JPE (2020) Vol.23 (1)

Tamás, $\mathbf{P}$.

Preliminary Note

\title{
SIMULATION INVESTIGATIONAL METHOD FOR COLLECTION AND DISTRIBUTION SYSTEMS
}

Received: 26 April 2020 / Accepted: 13 June 2020

\begin{abstract}
Collection and distribution material flow systems can be created using intermittent and/or continuous material handling equipment, the transformation of which is increasingly gaining ground, primarily as a result of changes in product structure, product volumes to be moved, and periodic process improvements. There are usually several alternatives for the transformation of the examined system, the best of which, due to the complexity of the examined system, requires in most cases the use of a simulation investigational method. The paper introduces the concept of a simulation testing method for selecting an appropriate process improvement alternative regarding the collection and distribution systems.
\end{abstract}

Key words: Logistics, simulation, investigational method, collection and distribution systems.

Simulacija istraživačkog metoda za sisteme prikupljanja i distribucije. Sistemi za prikupljanje i distribuciju protoka materijala mogu se kreirati korišćenjem isprekidane $i$ / ili neprekidne opreme za rukovanje materijalom, čija transformacija sve više dobija na značaju, pre svega kao rezultat promene u strukturi proizvoda, količine proizvoda koje treba premestiti $i$ periodičnih unapređenja procesa. Obično postoji nekoliko alternativa za transformaciju ispitivanog sistema, od kojih je jedna najbolja, a zbog složenosti ispitivanog sistema, u većini slučajeva potrebna je upotreba simulacione istraživačke metode. U radu je predstavljen koncept metode simulacije ispitivanja za izbor odgovarajuće alternative poboljšanja procesa u pogledu sistema za prikupljanje i distribuciju.

Ključne reči: Logistika, simulacija, istraživački metod, sistem za prikupljanje i distribuciju.

\section{INTRODUCTION}

The planning and transformation of collection and distribution material flow systems is becoming more and more important, mainly as a result of changes in the product structure and the quantities of products to be moved, as well as periodic process improvements [1-2]. Collection and distribution systems are typically used in the production and distribution logistics processes of a production company, and in many cases in the field of on-site material handling (e.g.: material supply to production lines and material handling between production lines and the finished product warehouse) [3]. Collection and distribution material flow systems are also used in various areas of service logistics, such as airport parcel delivery or mail collection and distribution systems. During the development of the examined system, several alternatives are usually elaborated, of which - due to the complexity of the examined system - it becomes necessary to apply a simulation investigational method. By using a properly performed simulation examination, the planning failures can be eliminated and the system version that best suits the company's criteria can be selected [4-6]. During the research carried out in recent years, I gained experience primarily with regard to the operation of collection and distribution systems created using continuous material handling machines, so the investigational method presented below is also limited to these types of systems. For collection and distribution systems operated using intermittent material handling machines, the following planning process needs to be corrected.

\section{SIMULATION INVESTIGATIONAL METHOD FOR SELECTING THE OPTIMAL OPERATING ALTERNATIVE}

The steps of the simulation investigational method to determine the selection of the optimal operating alternative are shown in Figure 1.

Simulation test process steps:

$\mathrm{A} / 1$. Defining the objectives of a simulation examination: The basic objective of selecting the optimal operational alternative is to avoid the planning failures and to select the ideal development alternative for the logistics system under examination. When examining the selection of the optimal operating alternative, by determining the operating characteristics and the requirements related to them, the variants containing the planning failures can be identified, which can be examined again after the required corrections have been made.

$\mathrm{A} / 2$. Delimitation of the examined system: The examined system (e. g. given production line, storage system, etc.) must be delimited, taking into account the investigational objectives. When delimiting, the input and output points of the system under examination and the processes to be examined must be fixed.

A/3. Study of the examined system: After defining the system, the person creating the simulation model must know in detail the material and information flow processes of the system under study. Particular attention should be paid to identifying individual processes. 


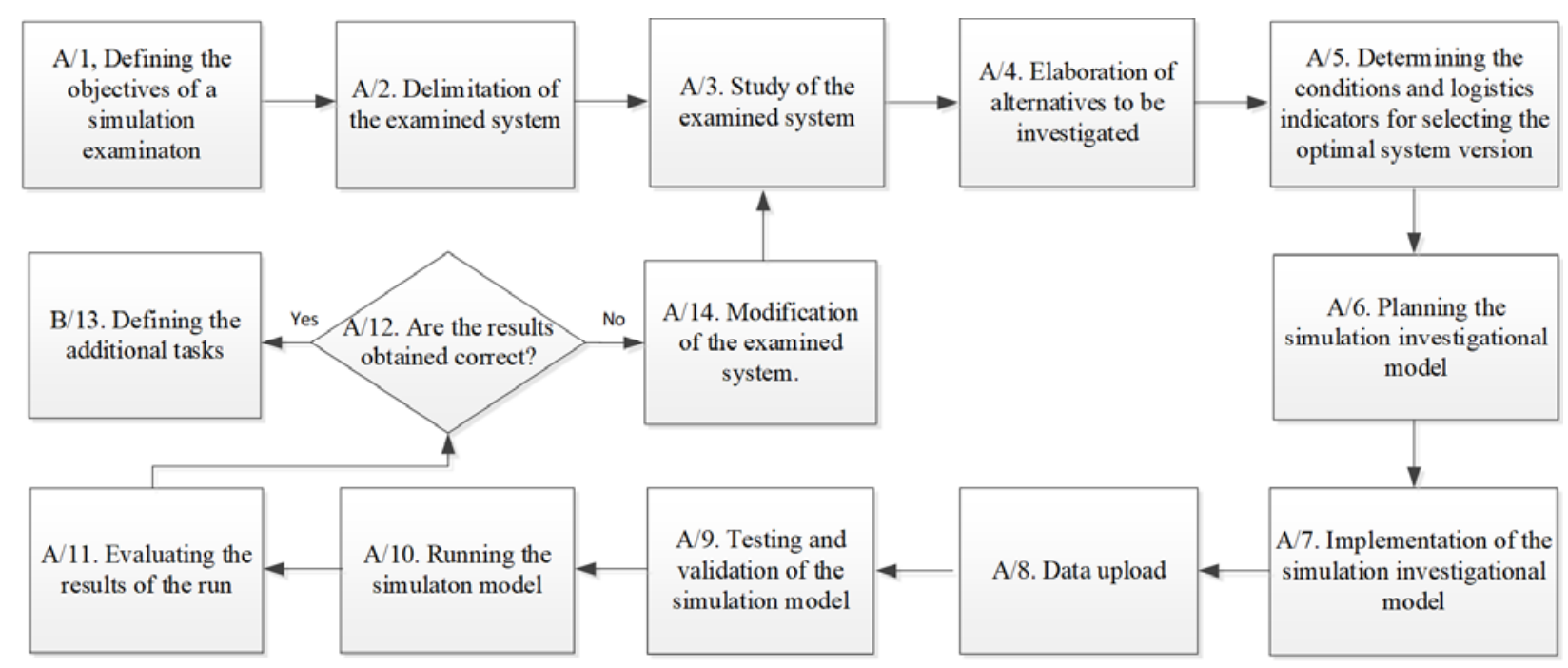

Fig 1. Simulation investigational method for selecting the optimal system version

A/4. Elaboration of alternatives to be investigated: The description of the processes of the operating system variants to be modeled should be implemented in this phase. With regard to the description, it is necessary to describe the material and information flow processes of the operating system variants to be examined, as well as the specifics characteristic of them.

$\mathrm{A} / 5$. Determining the conditions and logistics indicators necessary for selecting the optimal system version: One of the most important objectives in selecting the optimal system version is to identify planning failures and/or inoperable system versions, which can be detected by the requirements for operational characteristics. Correction of planning failures and/or exclusion from examination may be required for system version that do not meet expectations. Regarding the selection of the optimal system version, logistical indicators according to the company's criteria should be selected, together with various economic (e. g. operating costs, etc.) and subjective (eg overall impression of the examined version scored from 1 to 10 ) indicators.

A/6. Planning the simulation investigational model: In order to create the model, the examined material flow system(s), the data structures and algorithms necessary for the operation, as well as the decision method for the selection of the optimal operating system version must be determined. For the material flow system, the use of objects predefined by the simulation frameworks is recommended.

For the data structures of the simulation investigational model, it is recommended to create the following:

- System-level loading plan data table: A data row in Table 10 is the product (data field 4) and unit load forming device information (data field 5-6), the place and time of loading (data field 1-2) for a unit load with a given identifier (data field 3 ), and contains its place of delivery (Table 1).

- Loading program data table: Each loading location has a dedicated loading program data table, which must contain the data for that loading position. The data table structure is the same as the system-level loading plan data table structure. The data is uploaded by sorting the data series of the data table called the system-level loading plan, based on the loading location identifier.

\begin{tabular}{|l|c|}
\hline \multicolumn{1}{|c|}{ Data field } & Data type \\
\hline 1. Location of loading ID & String \\
\hline 2. Date of loading & Time \\
\hline 3. Unit load ID & String \\
\hline 4. Product type & String \\
\hline 5. Type of unit load forming device & String \\
\hline 6. Capacity of unit load forming device & Integer \\
\hline 7. Destination ID & String \\
\hline
\end{tabular}

Table 1. System-level loading plan data table

- Initial inventory level data table: The data table contains the initial inventory level data for unit loads and unit load forming devices. A row of the table shows the type (data field 2-3) and quantity (data field 6) of unit load and/or unit load forming device (data field 4-5; data field 7) of a given track section (data field 1), when starting the simulation program. In addition, the product delivery location identifier must be fixed in the data table (data field 8).

\begin{tabular}{|l|c|}
\hline \multicolumn{1}{|c|}{ Data field } & Data type \\
\hline 1. Track ID & String \\
\hline 2. Unit load ID & String \\
\hline 3. Product type & String \\
\hline 4. Type of unit load forming device & String \\
\hline 5. Capacity of unit load forming device & Integer \\
\hline 6. Quantity of unit load & Integer \\
\hline 7. Quantity of unit load forming device & Integer \\
\hline 8. Destination ID & String \\
\hline
\end{tabular}

Table 2. Initial inventory level data table

- Data table containing the operational characteristics of material flow nodes: This data table contains the data required to realize the operation of the material flow nodes. A row in the data table shows in which direction a unit load (data field 2) is to be forwarded for a given 
node (data field 1) (data fields 3-4). It also shows the priority (data field 5) for admission to the node for unit loads arriving from multiple directions. To properly assign the material flow direction, the unit load objects arriving at the node must contain the destination ID (it is also necessary to set the material flow directions for the different destinations for the track sections belonging to the node). The admission of unit loads to a node must be based on the value of the operational strategy (e. g. cyclic in the case of a value of 0 etc.).

\begin{tabular}{|l|c|}
\hline \multicolumn{1}{|c|}{ Data field } & Data type \\
\hline 1. Track ID & String \\
\hline 2. Speed & Real \\
\hline 3. Quantity of products to be blocked & Integer \\
\hline 4. Distance between unit loads & Real \\
\hline 5. Release time & Time \\
\hline
\end{tabular}

Table 3. Data table for the operating characteristics of material handling units

\begin{tabular}{|l|c|}
\hline \multicolumn{1}{|c|}{ Data field } & Data type \\
\hline 1. Node ID & String \\
\hline 2. Unit load ID & String \\
\hline 3. Destination ID & String \\
\hline 4. Material flow direction & String \\
\hline 5. Operational strategy & String \\
\hline
\end{tabular}

Table 4. Data table containing the operating characteristics of material flow nodes

Regarding the operational algorithm, the following is recommended: As a first step, the operational characteristics of the material handling units as well as the material flow nodes must be set in a simulation model based on the values of the data tables. The next step is to create the initial inventory levels based on the data in the initial inventory level data table. Based on the values of the system-level loading plan data table, the loading program data tables must be filled in, and then the loading and material flow of the movable units starts based on the data fixed in them. The operation of the nodes shall be implemented on the basis of the values of the data table containing the operational characteristics of the material flow nodes. During the running of the simulation model, it is necessary to create the values of the indicators for the selection of the optimal operatational system version, which is essential for the application of the decision method. This process should be repeated for each operational alternative. The best operational alternative can then be selected using the decision method presented below.

The proposed decision method for selecting the optimal operating system version is as follows: For some types of logistics indicators defined for the examined system versions, we strive to achieve the highest value (e. g. productivity, stock-out performance, etc.), while for other types we strive to achieve the lowest value (e. g. operating cost, floor space requirement, etc.) when selecting the optimal operatational system version. In order to be able to use the values of the logistics indicators to be minimized and to be maximized in an objective function, their normalized objective function components must be determined.

- Steps for creation of the objective funcion components to be minimized:

1. Determination of the average values of the logistics indicators to be minimized for all examined indicators.

2. The division of the minimum value and the average value of the logistics indicators and the part between the maximum value and the average value shall be divided into 5-5 equal intervals for each examined logistics indicator.

3. Transforming the logistics indicators of the studied versions to a value between 1 and 10 using the intervals defined in the previous step.

- Steps to create objective function components to be maximized:

1. Determining the average values of the logistics indicators to be maximized for all indicators.

2. The division of the minimum value and the average value of the logistics indicators and the part between the maximum value and the average value shall be divided into 5-5 equal intervals for each examined logistics indicator.

3. Transforming the logistics indicators of the studied versions to a value between 1 and 10 using the intervals defined in the previous step.

4. Convert the values to the objective function component to be minimized by subtracting the values from 1 to 10 defined in the previous step from 11. As a result of the normalization, the values of all logistic indicators were transformed between 1 and 10 , and the selection of the alternative with the lowest value for each objective function component became an objective.

- Objective function for selecting the optimal operating system version: Based on Equation (8), we form the weighted sum of the normalized objective function components for all operating system versions. After that, the version with the lowest value must be selected. Several methods can be used for weighting, such as averaging the weights given by the participants involved, the pairwise comparison method, or the Churchman-Ackoff weighting method.

$$
X=\operatorname{Min}_{i}\left\{\sum_{j=1}^{p} \delta_{j}^{*} Y_{i j}\right\} \quad 0 \leq \delta_{j} \leq 1 \quad \sum_{j=1}^{p} \delta_{j}=1
$$

where $\mathrm{i}$ is the examined version, $\mathrm{j}$ is the component identifier of the objective function, and is the weight of the objective function $\mathrm{j}$. (step A/13).

A/7. Implementation of the simulation investigational model: Based on the plans prepared for the system versions to be examined, the simulation investigational model must be created by creating an individual application or using a simulation framework. By using simulation frameworks, the efficiency of the examination can be increased, as we have the possibility to use predefined objects, evaluation and optimization 
functions.

A/8. Data upload: The defined data structures must be uploaded by manual data entry and/or data connections. Data can be uploaded using data generated during on-site measurements and/or provided by information systems.

A/9. Testing and validation of the simulation model: The operation of the simulation model prepared and filled with the necessary data must be tested and then validated. The implementation of this phase must be carried out in close cooperation between the persons performing the simulation examination and the representatives of the examined company. When testing the simulation model, the following types of failures may need to be corrected:

- incorrect data recording,

- inadequate data communication,

- inadequate material flow path,

- program errors.

After performing the necessary tests and corrections, the validation of the investigational model can be realized by checking the processes of the simulation investigational model and/or by comparing the data from the simulation investigational model and the real system.

A/10. Running the simulation model: After the validation of the simulation investigational model, the run can take place, during which the predefined logistics indicators and the objective function values for the selection of the optimal system version are determined for each investigational alternative.

A/11. Evaluating the results of the run: As a result of the run, possible planning failures are explored, and the system version that best suits the company's criteria can also be determined.

A/12. Examination of the acceptability of the results obtained: In the event that the results obtained are acceptable (the examined alternatives do not contain planning failures and/or the examination did not require a correction), a decision may be made to implement the selected system version (step A/13), otherwise a repeat investigational may be performed (step A/14).

\section{SUMMARY}

As the production and/or service environment changes, it may be necessary to periodically transform the collection and distribution systems to increase the efficiency of material flow processes. In the case of complex logistics systems, the reliability of the planning requires the use of simulation investigational methods. In the paper, a simulation investigational method for the selection of the optimal operating alternative that can be used during the transformation of collection and distribution systems was presented.

\section{REFERENCES}

[1] Cselényi, J., Illés, B.: Anyagáramlási rendszerek tervezése és irányítása I., Miskolci Egyetemi Kiadó,
ISBN: 9636616728, 2005.

[2] Cselényi, J., Illés, B.: Logisztikai rendszerek I. Miskolci Egyetemi Kiadó, Miskolc, 2004

[3] Illés, B., Glistau, E., Machado, N. I. C.: Logistik und Qualitätsmanagement, Miskolc, ISBN 978963- 87738-1- 4 (2007).

[4] Skapinyecz, R., Illés, B., \& Bányai, Á.: Logistic aspects of Industry 4.0. IOP Conference Series: Materials Science and Engineering Vol. 448, No. 1, p. 012014.(2018)

[5] Konyha, J., \& Bányai, T.: Sensor networks for smart manufacturing processe. Solid State Phenomena Vol. 261, pp. 456-462. (2017)

[6] Bányai, T. Supply chain optimization of outsourced blending technologies. Journal of Applied Economic Sciences 2017, 12(4):960-976.

\section{Acknowledgement}

The article was carried out as part of the Erasmus + ProdLog and EFOP-3.6.1-16-2016-00011 projects.

Authors: Assoc. Professor, head of the Institute Tamás Péter PhD, University of Miskolc, Faculty of Mechanical Engineering and Informatics, Institute of Logistics, Egyetemváros, 3515 Miskolc, Hungary, Phone.: +36 46 565-111.

E-mail: tamas.peter@uni-miskolc.hu 